\title{
PENGELOLAAN TANAMAN TERPADU PADI VARIETAS UNGGUL BARU DI LAHAN SAWAH TADAH HUJAN DI KABUPEN JAYAPURA, PAPUA
}

\author{
Petrus A. Beding ${ }^{1)}$ dan Batseba M. W. Tiro ${ }^{2)}$ \\ ${ }^{1,2}$ Balai Pengkajian Teknologi Pertanian Papua \\ Jl. Yahim Sentani-Jayapura, Telp. (0967) 592179 faks. 591235 \\ Email; peter.beding@yahoo.com
}

\begin{abstract}
The cultivation technology and the use of new superior varieties (VUB) is one of the main components in increasing rice productivity in rainfed land. The study aims to evaluate the performance of the rice VUB in rainfed lowland cultivated land with integrated crop management (PTT) approach. This activity was carried out in the village of Benyom Jaya 1, Nimbokrang District, Jayapura Regency, Papua Province, from April to September 2017 using a Randomized Group Design. each variety used is. VUB tested by Inpari, 7, Inpari 30, Inpari 32 and Inpari 33, were planted in a plot measuring 2 hectares of experimental area for each treatment was $20 \times 20 \mathrm{~m} 2$. The parameters evaluated include plant height, number of tillers, yield components and pest and disease attacks. The results of the study showed that the Inpari 33 variety gave a significantly different growth and yield to the Inpari 30 and 7 varieties. The suitable and high yielding varieties at the study site were the high production varieties obtained from the Inpari 33 variety (5.9 t/ ha) and the lowest variety is Inpari $32(4.47 \mathrm{t} / \mathrm{ha})$
\end{abstract}

Keywords: Rice Varieties, Rainfed Rice Fields, Performance, PTT

\section{PENDAHULUAN}

Penggunaan benih unggul merupakan salah satu faktor yang berpengaruh terhadap peningkatan produktivitas padi. Beberapa keuntungan yang dapat diperoleh dari penggunaan benih unggul diantaranya adalah mengurangi jumlah pemakaian benih dan tanam ulang serta memiliki daya kecambah dan tumbuh yang tinggi. Pertumbuhan awal yang kekar dapat mengurangi masalah gulma dan meningkatkan daya tahan tanaman terhadap serangan hama/penyakit sehingga kombinasi faktor ini dapat memberikan tambahan hasil 5-20\% (Abidin, 2011).

Salah satu upaya peningkatan produksi padi dapat dilakukan dengan menutup atau meminimalkan senjang hasil melalui introduksi varietas unggul baru (VUB) termasuk teknologi budidayanya. Introduksi VUB tersebut dilakukan melalui penelitian adaptasi di lahan petani dengan harapan teknologi dapat cepat menyebar di kalangan petani dan diadopsi oleh mereka. Pemilihan varietas secara partisipatif oleh petani merupakan pendekatan baru yang diyakini cukup efektif dan efisien dalam mempercepat adopsi dan penyebaran VUB, karena bertumpu pada keikutsertaan petani secara aktif dalam melihat keunggulan VUB dan petani akan memberikan preferensi (kesukaan) terterhadap VUB tersebut.

Penyediaan varietas unggul memegang peranan yang menonjol diantara berbagai teknologi yang dihasilkan melalui penelitian, baik dalam kontribusinya terhadap peningkatan produktivitas maupun sebagai salah satu komponen utama dalam pengendalian hama dan penyakit (Puslibang Tanaman Pangan, 1993). Selain itu, varietas unggul dinilai mudah diadopsi petani dengan tambahan biaya yang relatif murah dan memberikan keuntungan langsung kepada petani (Puslitbang Tanaman Pangan, 2000). Dengan semakin banyaknya varietas unggul yang dilepas, petani mempunyai banyak pilihan varietas yang sesuai dengan keinginan dan spesifik wilayahnya. Hal ini akan memperluas keragaman genetik tanaman di lapang sehingga dapat menekan risiko terjadinya ledakan hama dan penyakit tertentu. 
Pendekatan inovasi Pengelolaan Tanaman Terpadu (PTT) yang mengutamakan sinergisme berbagai komponen teknologi dalam suatu paket teknologi mampu meningkatkan efisiensi penggunaan input dan sekaligus hasil panen. PTT itu sendiri merupakan suatu pendekatan inovasi yang mempertimbangkan keserasian dan sinergisme antara komponen teknologi produksi (budidaya) dengan sumberdaya lingkungan setempat (Badan Litbang Pertanian, 2007). Dengan demikian, paket teknologi yang disiapkan bersifat spesifik lokasi, yang dapat menghasilkan sinergisme dan efisiensi tinggi, sebagai wahana pengelolaan tanaman dan sumberdaya spesifik lokasi (Hasanudin et al., 2000).

Beberapa hasil penelitian menunjukkan bahwa penerapan model PTT padi sawah dapat meningkatkan hasil gabah sebesar 1,0 ton/ha dibanding teknologi petani (non PTT). Penerapan model PTT padi sawah menggunakan varietas Membramo diperoleh gabah kering panen (GKP) 6,1-7,2 ton/ha (Rachman dan Saryoko, 2007). Selanjutnya Sirappa et al. (2006) melaporkan bahwa penerapan PTT menggunakan varietas Ciherang diperoleh hasil GKP 7,6-8,2 ton/ha sedangkan teknologi petani hanya 4,3 ton/ha. Arafah (2011), melaporkan bahwa penggunaan VUB padi sawah dengan penerapan PTT dapat meningkatkan hasil GKG sebesar $11,1 \%$ dan peningkatan keuntungan sebesar 23,1\% dibandingkan dengan varietas lokal. Berbagai upaya yang dilakukan untuk pencapaian hal tersebut adalah melalui peningkatan peran inovasi teknologi VUB padi dan pelaksanaan inovasi pengelolaan tanaman terpadu (Pikukuh et al., 2007; Suhendrata et al., 2008).

Sembiring (2008), mengemukakan bahwa salah satu VUB padi yang memiliki cita rasa nasi pulen dan produksinya lebih tinggi daripada varietas IR64 adalah Mekongga. Walaupun pada beberapa tahun terakhir ini, Indonesia mengalami pelandaian laju peningkatan produksi padi sawah sebagai akibat alih fungsi lahan pertanian ke non pertanian, namun peluang peningkatan produktivitas dan produksi padi masih terbuka lebar, antara lain melalui penerapan inovasi teknologi VUB padi inbrida dengan produktivitas tinggi (Badan Litbang Pertanian, 2007).

Selain hal tersebut, para petani belum menggunakan inovasi teknologi dasar PTT seperti pemberian bahan organik melalui pengembalian jerami ke sawah, pengaturan populasi tanaman secara optimum dengan tanam jajar legowo, pemupukan berdasarkan kebutuhan tanaman dan status hara tanah, dan pengendalian organisme pengganggu tanaman (OPT) dengan pendekatan pengendalian hama terpadu (PHT). Sehubungan dengan hal tersebut, maka peningkatan produksi padi menghadapi tantangan yang makin berat dari tahun ke tahun disebabkan antara lain semakin menciutnya lahan sawah produktif, terbatasnya lahan subur serta ancaman iklim dan hama penyakit yang dapat muncul sewaktu-waktu serta pengunaan VUB.

Luas areal tanam padi di Kabupaten Jayapura 1.142 ha, produksi 4.900 ton dan produktivitas padi sawah 4,5 ton/ha (BPS Papua, 2016). Berdasarkan data tersebut, rataan tingkat produktivitas padi masih rendah dibandingkan potensi hasil yang dapat mencapai 8,0 t/ha (Balai Besar Penelitian Tanaman Padi, 2011). Beberapa penyebab rendahnya produksi padi adalah telah tercapainya potensi hasil optimum dari VUB yang ditanam petani, terbatasnya kemampuan genetik VUB yang ada, penggunaan varietas yang sama pada suatu wilayah dalam kurun waktu yang lama dapat menyebabkan cepatnya proses pematahan ketahanan varietas terhadap OPT dan serangan OPT (Abdullah et al., 2008; Suprihatno et al., 2009). Oleh karena itu diperlukan introduksi dan adaptasi VUB padi yang mempunyai produktivitas tinggi dan memiliki ketahanan hama dan penyakit.

Budidaya padi dengan pendekatan PTT mengunakan benih bermutuh tinggi $20 \mathrm{~kg} / \mathrm{ha}$, umur bibit ditanam 21 hari setelah disemai, 1 - 3 bibit per lubang tanam, dan ditanam dengan sistim jajar legowo (Wahid 2010; Abduraman et.al, 2011; Sirapa dan Wahid 2012; Baniek dan Abidin 2013; dalam Elsera et al. 2014). Penanaman padi dengan sistim jajar legowo meningkatkan populasi persatuan luas melalui pengaturan jarak tanam dan memberikan keuntungan yang lebih tinggi karena hasil gabah lebih tinggi. Peningkatan hasil padi dengan cara tanam jajar legowo dipengaruhi oleh peningkatan populasi tanaman pingir. Dua baris rumpun padi pada barisan pinggir pertanaman jajar legowo 2:1 menigkatkan intersepsi sinar matahari pada tanaman yang diperlukan dalam proses fotosintesis (Suhendra, 2008) 
Pengkajian bertujuan untuk untuk mengevaluasi keragaan varietas unggul padi di lahan sawah tadah hujan Kabupten Jayapura, Papua yang dibudidayakan dengan pendekatan PTT.

\section{METODE PENELITIAN}

Pengkajian dilaksanakan di lahan milik petani seluas 2,0 ha di Kampung Benyom Jaya 1, Distrik Nimborang Kabupaten Jayapura mulai bulan April sampai dengan September 2017, melibatkan empat petani kooperator, masing-masing-masing pada lahan seluas 0,5 ha. Pada tiap unit percobaan ditanam (empat) variatas unggul baru yaitu Inpari 7, Inpari 30, Inpari 32 dan Inpari 33. Rancangan yang digunakan adalah rancangan Acak Kelompok (RAK) yang diulang sebanyak 4 kali, masing masing perlakuan dengan ukuran plot seluas $20 \times 20 \mathrm{~m}^{2}$ Cara tanam mengunakan sistem jajar legowo 2:1 dengan jarak tanam $(40 \times 20) \times 10$.

Pengolahan tanah dilakukan secara sempurna dengan mengunakan traktor, yaitu bajak satu kali kemudian digaru diratakan. Pemupukan P diberikan berdasarkan hasil perangkat uji tanah sawah (PUTS) yaitu Phoska 200 kg/ha, Pupuk P diberikan umuur 7-10 setelah tanam. Sedangkan Pemupukan urea dilakukan berdasarkan pengamatan dengan mengunakan bagan daun/leaf Colur Chart dimulai pada umur 14 hst dengan interval 7-10 hari,sehingga dosis urea yang diberikan mencapai $150 \mathrm{~kg} / \mathrm{ha}$ dengan dua kali aplikasi. Pada saat pemupukan dan pengendalian gulma dilakukan dalam keadaaan sawah macak-macak. Pengendalian gulma dilakukan dengan mengunakan herbisida pratumbuh yang dikombinasikan dengan penyiangan secara manual sesuai dengan kebutuhan dilapangan. sedangkan pengendalian hama dan penyakit berdasarkan Pengendalian Hama Terpadu (PHT).

Peubah yang diamati anatara lain Komponen pertumbuhan dan produksi meliputi tinggi tanaman (cm), jumlah anakan, jumlah malai), jumlah gabah hampa, hasil per hektar (ton/ha), tingkat kerusakan. Data terkumpul dianalisis mengunakan analisis ragam. Juka hasil uji menunjukan beda nyata atau sangat nyata, dilanjutkan dengan Berganda Dunkan atau Duncan's Multiple Range Test (DMRT) sesuai taraf uji dalam analisis ragam.

Sedangkan analisis data usahatani dilakuakan dengan analisis finensial dengan $\mathrm{R} / \mathrm{C}$ dan $\mathrm{B} / \mathrm{C}$. Analisis data dilakukan dengan alisis finensial untuk mengetahui tingkat kelayakan teknologi yang diintroduksikan. Analisis yang digunakan diantaranya adalah: (Swastika, 2004)

1. Analisis pendapatan dan keuntungan,

2. Analisis imbangan penerimaan atas biaya $\mathrm{R} / \mathrm{C}$ dengan rumus : $\mathrm{R} / \mathrm{C}=\underline{\text { Total penerimaan }}$ Total biaya

3. Analisis imbangan penerimaan atas biaya $\mathrm{R} / \mathrm{C}$ dengan rumus : $\mathrm{B} / \mathrm{C}=$ Total pendapatan Total biaya

\section{HASIL DAN PEMBAHASAN Karakeristik Wilayah}

Kabupaten Jayapura merupakan salah satu wilayah administrasi di Provinsi Papua yang terletak antara $139^{\circ} 15^{\prime}-140^{\circ} 45^{\prime}$ Bujur Timur dan antara $2^{\circ} 15^{\prime}-3^{\circ} 45^{\prime}$ Lintang Selatan. Luas wilayah Kabupaten Jayapura adalah 17.516,6 $\mathrm{km}^{2}$ yang terdiri dari 19 Distrik (Kecamatan). Batas wilayah Kabupaten Jayapura meliputi: sebelah Utara berbatasan dengan Samudera Pasifik dan Kabupaten Sarmi, sebelah Selatan berbatasan dengan Kabupaten Pegunungan Bintang, Kabupaten Yahukimo dan Kabupaten Tolikara, sebelah Timur berbatasan dengan Kota Jayapura dan Kabupaten Keerom, dan sebelah Barat berbatasan dengan Kabupaten Sarmi.

\section{Keragaan Teknologi Eksisting Padi Sawah Tadah Hujan}

Salah satu faktor keberhasilan pengelolaan usahatani padi ditentukan melalui penggunaan input produksi. Penggunaan input produksi yang optimal akan menghasilkan produksi yang maksimal dan pada akhirnya memberikan keuntungan usahatani yang relatif tinggi. Dosis anjuran penggunaan input produksi seperti pemupukan sudah diketahui petani, namun pada prakteknya tidak semua petani menerapkan dosis anjuran. Belum dilaksanakannya penggunaan dosis pupuk oleh petani lebih banyak disebabkan oleh daya beli petani yang masih rendah. Berdasarkan hasil diskusi dengan petani dan penyuluh lapangan diketahui bahwa usahatani padi sawah tadah hujan yang dilaksanakan petani dengan kisaran luas garapan 0,50-1,0 ha (rata-rata 0,75 ha/petani). Petani masih menggunakan varietas yang tersedia di lapangan, yang bersumber dari hasil 
panen sendiri dan benihnya berasal dari bantuan pemerintah daerah yang merupakan benih turunan (telah digunakan secara terus menerus selama lima tahun terakhir).

Petani hanya menggunakan pupuk an organik (pupuk buatan) dan tidak ditemukan petani yang menggunakan pupuk organik untuk pertanaman padi sawah. Penggunaan dosis pupuk ini diduga masih jauh dari rekomendasi yaitu urea $200 \mathrm{~kg} / \mathrm{ha}$, SP36 50 $\mathrm{kg} / \mathrm{ha}$ dan KCL $50 \mathrm{~kg} / \mathrm{ha}$.

Petani menggunakan benih jauh lebih banyak dari anjuran. Jika dilihat dari tingkat penggunaan benih yang tinggi dari penggunaan benih rekomendasi (30-40 kg/ha), disebabkan ketidak yakinan petani terhadap kualitas benihnya. Menurut Daradjad et al. (2008), benih padi yang digunakan oleh masyarakat lebih dari $60 \%$ berasal dari sektor informal yaitu berupa gabah yang disisihkan dari hasil panen musim sebelumya yang dilakukan berulang-ulang.

\section{Komponen pertumbuhan tanaman}

Data komponen pertumbuhan yang meliputi tinggi tanaman dan jumlah anakan produktif diperlihatkan dalam Tabel 1. Tabel 1, menunjukan bahwa rata-rata tinggi tanaman saat panen menunjukkan bahwa varietas Inpari 7 memiliki tinggi tanaman paling tinggi $98,18 \mathrm{~cm}$ diikuti oleh Inpari $30(89,65 \mathrm{~cm})$ dan yang terendah varietas Inpari $33(73,13 \mathrm{~cm})$. Hasil analisis statistik menunjukkan bahwa tinggi tanaman dari keempat varietas yang dikaji berpengaruh nyata $(\mathrm{P}<0,05)$.

Perbedaan tinggi tanaman dari empat varietas yang di uji ini diduga karena sifat genetik dari varietas dan pengaruh keadaan lingkungan. Tinggi tanaman juga merupakan salah satu kriteria seleksi pada tanaman padi, tetapi pertumbuhan yang tinggi belum menjamin tingkat produksinya (Suprapto dan Dradjat, 2005). Pertumbuhan merupakan proses dalam kehidupan tanaman yang mengakibatkan perubahan ukuran, pertambahan bobot, volume dan diameter batang dari waktu ke waktu. Keberhasilan pertumbuhan suatu tanaman dikendalikan oleh faktor-faktor pertumbuhan. Ada dua faktor penting yang berpengaruh dalam pertumbuhan suatu tanaman, yaitu faktor genetik dan faktor lingkungan. Faktor genetik berkaitan dengan pewarisan sifat/perilaku tanaman itu sendiri, sedangkan faktor lingkungan berkaitan dengan kondisi lingkungan dimana tanaman itu tumbuh. Setiap varietas tanaman memiliki kemampuan yang berbeda dalam hal memanfaatkan sarana tumbuh dan kemampuan untuk melakukan adaptasi dengan lingkungan sekitar, sehingga mempengaruhi potensi hasil tanaman.

Tabel 1. Rata-rata hasil pengukuran tinggi anaman (cm) dan jumlah anakan produktif (anakan) masing-masing perlakuan.

\begin{tabular}{lccc}
\hline No. Varietas & $\begin{array}{c}\text { Tinggi } \\
\text { tanaman } \\
\text { maksimum } \\
(\mathrm{cm})\end{array}$ & $\begin{array}{c}\text { Jumlah anakan } \\
\text { produktif } \\
\text { rumpun/batang }\end{array}$ \\
\hline 1. & Inpari 7 & $98,18 \mathrm{a}$ & $14,85 \mathrm{~b}$ \\
2. & Inpri 30 & $89,65 \mathrm{a}$ & $13,12 \mathrm{c}$ \\
3. & Inpari 33 & $73,13 \mathrm{~b}$ & $16,63 \mathrm{a}$ \\
4. & Inpari 32 & $98,80 \mathrm{a}$ & $16,35 \mathrm{a}$ \\
\hline KK (\%) & 8,74 & 3,44 \\
\hline Keterangan : Huruf yang sama pada kolom yang sama \\
\multicolumn{4}{c}{ menunjukkan tidak berbeda nyata berdasarkan } \\
\end{tabular}

Selanjutnya jumlah anakan produktif berkorelasi positif terhadap jumlah malai yang dihasilkan. Makin banyak anakan produktif makin tinggi gabah yang akan diperoleh. Rataan jumlah anakan produktif tidak memperlihatkan perbedaan yang nyata pada setiap varietas yang dikaji. Hal ini disebabkan varietas yang ditanam mampu beradaptasi baik pada kondisi lingkungan tumbuh maupun di lahan sawah tadah hujan. Kemampuan membentuk anakan produktif dipengaruhi oleh interaksi sifat genetik varietas dan lingkungan tumbuhnya (Endrizal dan Bobihoe, 2010). Jumlah anakan produktif tertinggi di peroleh dari varietas Inpari 33 (16,63 rumpun/batang) dan yang terendah dari varietas Inpari 30 (9,87 rumpun/batang) (Tabel 2). Analisis statistik menunjukkan bahwa jumlah anakan produktif dari keempat varietas yang dikaji nyata dipengaruhi olehh varietas $(\mathrm{P}<0,05)$. Jumlah anakan produktif per rumpun atau per satuan luas merupakan penentu terhadap jumlah malai yang merupakan salah satu komponen hasil yang berpengaruh langsung terhadap tinggi rendahnya hasil gabah (Simanulang, 2001). Semakin banyak anakan produktif maka semakin banyak jumlah malai yang terbentuk.

Terdapat korelasi antara jumlah malai dengan hasil karena semakin banyak jumlah malai semakin 
tinggi hasil tanaman padi seperti yang dilaporkan Muliadi dan Pratama (2008) Jumlah anakan padi juga berkaitan dengan periode pembentukan phyllochron. Phyllochron adalah periode munculnya satu sel batang, daun dan akar yang muncul dari dasar tanaman dan perkecambahan selanjutnya. Semakin tua bibit dipindah ke lapang, semakin sedikit jumlah phyllochron yang dihasilkan, sedangkan semakin muda bibit dipindahkan, semakin banyak jumlah phyllochron yang dihasilkan sehingga anakan yang dapat dihasilkan juga semakin banyak (Sunadi, 2008).

Komponen hasil berdasarkan pengamatan komponen produksi tanaman disajikan dalam Tabel 2.

Tabel 2. Rata-rata hasil pengukuran jumlah malai dan produksi padi.

\begin{tabular}{llcl}
\hline No & Uraian & $\begin{array}{c}\text { Jumlah malai } \\
\text { batang/rumpun }\end{array}$ & $\begin{array}{c}\text { Produksi } \\
\text { GKG } \\
(\mathrm{t} / \mathrm{ha})\end{array}$ \\
\hline 1. & Inpari 7 & $14,70 \mathrm{c}$ & $5,10 \mathrm{c}$ \\
2. & Inpri 30 & $13,05 \mathrm{~d}$ & $5,51 \mathrm{~b}$ \\
3. & Inpari 33 & $16,60 \mathrm{a}$ & $5,91 \mathrm{a}$ \\
4. & Inpari 32 & $15,58 \mathrm{~b}$ & $4,79 \mathrm{~d}$ \\
\hline KK (\%) & 2,33 & 1,65 \\
\hline Keterangan: & Huruf yang sama pada kolom & yang sama \\
& menunjukkan tidak berbeda nyata berdasarkan \\
& Uji Duncan pada taraf 5\%.
\end{tabular}

Data pada Tabel 3, menunjukkan bahwa jumlah malai berkisar antara 13,05-16,60, dan jumlah malai terbanyak diperoleh pada varietas Inpari $33(16,60)$ dan terendah pada varietas Inpari 30 (13,05). Secara statistik jumlah malai dari empat varietas yang dikaji berpengaruh nyata $(\mathrm{P}<0,05)$. Dari ketiga komponen yang diamati ada dua komponen yang berhubungan lansung dengan produktivitas, semakin banyak jumlah anakan semakin berpeluang untuk menghasilkan jumlah malai yang banyak pula. Begitupun terhadap panjang malai semakin panjang malai tanaman maka peluang untuk menghasilkan biji gabah semakin banyak juga.

Produksi gabah kering panen (GKP) tertinggi diperoleh dari varietas Inpari 33 yakni 5,91 t/ha, diikuti Inpari 30 (5,51 t/ha) dan Inpari 7 (5,10 t/ha). Sedangkan produksi GKP terendah yakni varietas
Inpari $32(4,79$ t/ha). Secara statistik produksi GKP dari empat varietas yang dikaji berpengaruh nyata ( $\mathrm{P}<0,05)$. Sirappa et al. (2009), menyatakan bahwa introduksi VUB yang didukung teknologi mampu memberikan hasil 21-54\% lebih tinggi. Apabila dibandingkan dengan produktivitas eksisting di lapangan yang hanya berkisar antara 2,7 - 3,5 t/ha, Hal ini menunjukkan bahwa pencapaian hasil suatu varietas harus didukung oleh teknologi dan lingkungan yang optimal.

Berdasarkan produksi GKP tersebut, masih ada peluang untuk meningkatkan produksi dari keempat varietas yang dikaji jika teknologi yang digunakan tepat guna. Tinggi dan rendahnya produktivitas tergantung dari teknologi yang diterapkan dan kesesuaian iklim di lahan setempat. Semakin baik teknologi yang diterapkan dengan kondisi iklim yang mendukung, produktivitas yang dicapai akan lebih tinggi.

Penerapan sistem tanam jajar legowo 2:1 juga berpengaruh terhadap produksi. Menurut Sutardjo (2012), salah satu faktor untuk meningkatkan produktivitas dengan diterapkannya cara tanam sistem jajar legowo 2:1 yang menambah barisan tanaman untuk mengalami efek tanaman pinggir, sinar matahari dapat dimanfaatkan lebih banyak untuk proses fotosintesis dan pemeliharaan lebih mudah. Hal ini disebabkan makin luas lorong yang terdapat pada sistem tanam jajar legowo mengakibatkan intensitas cahaya matahari yang sampai ke permukaan daun lebih banyak terutama pada pinggir lorong sehingga meningkatkan efisiensi fotosintesis (Abdullah, 2000). Laju serapan hara oleh akar tanaman cenderung meningkat dengan meningkatnya intensitas cahaya matahari, Fagi dan De Datta (1981).

\section{Analisis Finansial Usahatani Tanaman Padi Sawah}

Bekembangnya suatu teknologi yang diterapkan dalam usahatani yang dijalankan dipengaruhi oleh tingkat keuntungan dari masingmasing varietas padi sawah tadah hujan dilakukan . analisis finensial usahatani padi sawah tadah hujan yang diterapkan petani di lokasi kegiatan, disajikan pada Tabel 3. 
Tabel 3. Analisis finansial usahatani padi sawah di lahan tadah hujan Kampung Benyom Jaya Disrik Nimbokrang secara finansial perhitungan kelayakan usahatani masing-masing varietas padi Nimbokrang Jayapura 2017

\begin{tabular}{lrrrr}
\hline Uraian & \multicolumn{4}{c}{ Varietas } \\
\cline { 2 - 5 } & Inpari 7 & Inpari 30 & Inpari 32 & Inpari 33 \\
\hline Input (Rp) & & & \\
Bahan & 3.930 .000 & 3.930 .000 & 3.930 .000 & 3.930 .000 \\
Tenaga kerja & 5.625 .000 & 5.625 .000 & 5.625 .000 & 5.625 .000 \\
Total biaya & 9.555 .000 & 9.555 .000 & 9.555 .000 & 9.555 .000 \\
Penerimaan & 22.545 .000 & 22.729 .500 & 22.909 .500 & 22.909 .500 \\
Keutungan & 12.990 .000 & 13.174 .500 & 8.800 .500 & 13.174 .500 \\
Gross R/C & 2,4 & 2,4 & 1,9 & 2,4 \\
Marginal B/C & 1,4 & 1,4 & 0,9 & 1,4 \\
\hline
\end{tabular}

Penerapan teknologi baru berupa introduksi VUB padi sawah yang diintroduksi memberikan pengaruh terhadap usatani. Tabel 3. menunjukkan bahwa tingkat keuntungan yang diperoleh dari empat varietas unggul yang diterapkan Rp. 8.800.500-22.909.500/ha. Hasil analisis B/C dari penerapan varietas unggul memperlihatkan angka yang cukup tinggi dari 1,9-2,4. Ini berati dari seriap Rp.1 biaya yang dikeluarkan mampu memberikan imbalan sebesar Rp 1,9 - 2,4. Dengan demikian usahatani ini dianggap layak untuk diusahakan karena nilai B/C Ratio > 1 (Suratiyah Ken, 2006)

\section{KESIMPULAN}

1. VUB inpari 30 dan Inpari 33 merupakan VUB padi sawah yang adaptif pada lingkungan spesifik lokasi di Kabupaten Jayapura dan memberikan hasil berturut-turut 4,47-5,91 t/ha.

2. Untuk meningkatkan produksi padi sawah tadah hujan di kabupaten Jayapura disarankan untuk mengembangkan ke dua VUB ( Inapri 30 dan Inpari 33)

\section{UCAPAN TERIMA KASIH}

Pada kesempatan ini penulis mengucapakan terima kasih kepada Kepala Balai Pengkajian Teknologi Pertanian Papua atas kesempatan dan bimbingan dalam melakukan kajian dan penyusunan karya tulis ini.

\section{DAFTAR PUSTAKA}

Abdullah, S. 2000. Teknologi P-starter dengan Sistem Tanam Legowo (Shaf) Pada Budidaya Padi Sawah. Prosiding Seminar Nasional Hasil-hasil Penelitian dan Pengkajian Pertanian. Buku I. Sukarami, 21-22 Maret 2000. Puslitbang Sosial Ekonomi Pertanian Bogor; 76-81 hlm.

Abdullah, B., S.Tjokrowidjojo dan Sularjo. 2008. Perkembangan dan prospek perakitan padi tipe baru di Indonesia. Jurnal Penelitian dan Pengembangan Pertanian. Badan Litbang Pertanian. Vol. 27 (1)

Abidin Z. 2011. Analisis struktur biaya, keuntungan dan titik impas usaha penangkaran benih padi di Kabupaten Konawe Sulawesi Tenggara. JurnalPengkajian dan Pengembangan Teknologi Pertanian.14(2):91-99.

Arafah. 2011. Kajian Pemanfaatan Pupuk Organik Pada Tanaman Padi Sawah di Pinrang Sulawesi Selatan. Jurnal Pengkajian dan Pengembangan Teknologi Pertanian . 14 (1): $11-18$.

Baehaki,S.E.2011.Strategi fundamental pengendalian hama wereng batang cokelat dalam pengamanan produksi padi nasional. Pengembangan InovasiPertanian. Badan Penelitian dan Pengembangan Pertanian 4(1):63-75.

Badan Litbang Pertanian. 2007. Pengelolaan Tanaman Terpadu (PTT) Padi Sawah. Petunjuk Teknis Lapang. Badan Litbang Pertanian, Kementan, Jakarta. p 46. 
Badan Pusat Statistik Papua. 2016. Papua Dalam Angka Provinsi Papua. Badan Pusat Statistik Papua.

Balai Besar Penelitian Tanaman Padi. 2011. Deskripsi Varietas Padi. Badan Litbang Pertanian, Kementerian Pertanian.p.8.

Baniek, S. dan Z. Abidin, 2013. Faktor-faktor sosial ekonomi yang mempengaruhi adopsi teknologi pengelolaan tanaman terpadu padi sawa di sulawesi Tengara, Jurnal Pengkajian dan pengembangan Teknologi Pertanian 16(2):89-97.

Daradjat, A.A., Setyono A, Makarim AK, A. Hasanuddin. 2008. Padi-InovasiTeknologi Produksi. Buku 2. LIPI Press. Jakarta. p. 6789.

Endrizal dan J. Bobihoe. 2010. Pengujian beberapa galur unggulan padi dataran tinggi di Kabupaten Kerinci Propinsi Jambi. Jurnal Pengkajian dan Pengembangan Teknologi Pertanian 13(3): 175-184.

Elsera,T. Jumali, dan B. Kusbiantoro, 2014. Karakterisasi flavor beras varietas padi aromatik dari ketinggian lokasi berbeda. Jurnal Penelitian Pertanian Tanaman Pangan 33(1)175-184.

Handoko dan M. Purwoko. 2007. Inovasi varietas padi. Balai Pengkajian Teknologi Jawa Timur $9 \mathrm{p}$.

Hasanuddin, A., S.E. Baihaki, S.J. Munarso dan Sutisna Noor. 2000. Teknologi unggulan peningkatan produksi padi menuju revolusi hijau generasi kedua. Simposium Penelitian Tanaman Pangan IV. Puslitbang Tanaman Pangan, Bogor. 154-165.

Muliadi A., R. Heru Pratama. 2008. Korelasi Antara Komponen Hasil dan Hasil Galur Harapan Padi Sawah Tahan Tungro.Prosd. Seminar Nasional Padi; Inovasi teknologi padi mengantisipasi perubahan iklim global mendukung ketahanan pangan (1):165-171. Balai Besar Penelitian Tanaman Padi. Sukamandi.

Pusat Penelitian dan Pengembangan Tanaman Pangan. 1993. Deskripsi Varietas Unggul Padi
1943-1992. Badan Litbang Pertanian. Departemen Pertanian.p. 123.

Pusat Penelitian dan Pengembangan Tanaman Pangan. 2000. Deskripsi Varietas Unggul Tanaman Padi dan Palawija. 1999-2000. Badan Litbang Pertanian. Departemen Pertanian. P.113.

Rachman, B. dan A. Saryoko. 2007. Analisis sensitivitas padi sawah di lebak Banten. Jurnal Pengkajian dan Pengembangan Teknologi Pertanian . 14(2): 91-99.

Sembiring, H. 2008. Kebijakan penelitian dan rangkuman hasil penelitian $\mathrm{BB}$ Padi dalam mendukung peningkatan produksi beras nasional. Prosiding Seminar Apresiasi Hasil Penelitian Padi Menunjang P2BN. Balai Besar Penelitian Tanaman Padi. Sukamandi, Subang : 39-59 hlm.

Simanulang, Z.A. 2001. Kriteria seksi untuk sifat agronomis dan mutu. Pelatihan dan Koordinasi Progam Pemuliaan Partisipatif (Shuttle Breeding dan Uji Multilokasi). Sukamandi 9-14 April 2001. Balitpa. Sukamandi.

Swastika D.K.S. 2004. Beberapa teknis Analisis Dalam Teknologi Pertanian Pertanian. 7(1). 90-103. Pulitbang Sosial Ekonomi Pertanian, Bogor.

Suprapto dan A.A. Daradjat. 2005. Evaluasi Beberapa Galur Harapan Padi Sawah di Bali. Buletin Plasma Nutfah 11(1):6-10.

Suratiyah Ken, 2006, Ilmu Usahatani. Penebar Swadaya. Jakarta. P.156.

Sirappa M.P, A.N. Susanto dan Y. Toha. 2006. Kajian usahatani padi sawah varietas unggul tipe baru dengan pendekatan pengelolaan Tanaman terpadu. Jurnal Pengkajian dan Pengembangan Teknologi Pertanian. 9(1):18-28.

Suhendrata, T., E.Kushartanti, dan S.J. Munarso. 2008. Keragaan beberapa varietas unggul baru padi di lahan sawan irigasi desa Pulir, Kecamatan Mojolaban, Kabupaten Sukohardjo. Prosiding Seminar Apresiasi Hasil Penelitian Padi Menunjang P2BN. Buku 1.Balai Besar penelitian Tanaman Padi.Badan Penelitian dan Pengembangan Pertanian. 
2008. p. 245-264. Editor, Bambang

Suprihanto ... [et al] ... Tahun Terbit.2008.

Sunadi. 2008. Modifikasi paket teknologi SRI (The System or Rice Intensification) untuk meningkatkan hasil padi sawah (Oryza sativa. L). Disertasi Doktor Ilmu Pertanian pada Program Pasca Sarjana Universitas Andalas. Padang. 235p.

Suhendra, T. 2008 Peran Inovasi teknologi pertanian dalam peningkatan produktivitas padi sawah untuk mendukung ketahanan pangan. Prosiding Seminar Nasional Teknik Pertanian, Yogyakarta. p. 15.

Sirappa M.P, dan E.D.Waas. 2009. Kajian varietas dan pemupukan terhadap peningkatan hasil padi sawah di Maluku Tengah. Jurnal Pengembangan Teknologi Pertanian.12(1): 79-90.

Suprihatno, B., Estria Furry P., Widarto Y.P., Poniman, G. Kustiono, Mardjuki dan A. Bastian. 2009. Keragaan Galur-galur Padi sawah Generasi Menengah pada Berbagai Agroekosistem. Dalam B. Suprihatno et al (ed) Inovasi Teknologi padi mengantisipasi Perubahan Iklim Global Mendukung ketahanan Pangan. Buku 1. Badan Litbang Pertanian 937-1329p.

Sutardjo, W. 2012. Tanam Padi Sistem Jajar Legowo.http://sekarmadjapahit.wordpress.co $\mathrm{m} / 2012 / 01 / 30 /$ tanam-padi-sistem-jajarlegowo/ (21 Juli 2018).

Sirappa M.P dan Wahid 2012. Keragaandan potensi beberapavarietas padi pada lahan sawah bukaan baru. Jurnal BudidayaPertanian 6(2): 84-94. 